\section{BMJ Paediatrics Open}

\title{
Paediatric sickle cell disease at a tertiary hospital in Malawi: a retrospective cross-sectional study
}

Chikondi Sharon Chimbatata (D) , ${ }^{1}$ Master RO Chisale (D) ,,3

Alfred Bornwell Kayira, ${ }^{3}$ Frank Watson Sinyiza, ${ }^{4}$ Balwani Chingatichifwe Mbakaya (1) , ${ }^{5}$ Paul Uchizi Kaseka, ${ }^{1}$ Pocha Kamudumuli, ${ }^{6}$ Tsung-Shu Joseph Wu (iD ${ }^{7,8}$

To cite: Chimbatata CS, Chisale MRO, Kayira AB, et al. Paediatric sickle cell disease at a tertiary hospital in Malawi: a retrospective cross-sectional study. BMJ Paediatrics Open 2021;5:e001097. doi:10.1136/ bmjpo-2021-001097

- Additional supplemental material is published online only. To view, please visit the journal online (http://dx.doi.org/ 10.1136/bmjpo-2021-001097).

Received 19 March 2021 Accepted 13 August 2021

Check for updates

(C) Author(s) (or their employer(s)) 2021. Re-use permitted under CC BY-NC. No commercial re-use. See rights and permissions. Published by BMJ.

For numbered affiliations see end of article.

Correspondence to Chikondi Sharon Chimbatata; chimbatatachikondi@gmail.com

\section{ABSTRACT}

Introduction Sickle cell disease (SCD) remains a major cause of childhood mortality and morbidity in Malawi.

However, literature to comprehensively describe the disease in the paediatric population is lacking.

Methods A retrospective review of clinical files of children with SCD was conducted. Descriptive statistics were performed to summarise the data. $\chi^{2}$ or Fisher's exact test was used to look for significant associations between predictor variables and outcome variables (case fatality and length of hospital stay). Predictor variables that were significantly associated with outcome variables $(p \leq 0.05)$ in a $\chi^{2}$ or Fisher's exact test were carried forward for analysis in a binary logistic regression. A multivariable binary logistic regression was used to identify covariates that independently predicted length of hospital stay.

Results There were 16333 paediatric hospitalisations during the study period. Of these, 512 were patients with SCD representing 3.1\% (95\% Cl: 2.9\%- 3.4\%). Sixty-eight of the 512 children ( $13.3 \%$; $95 \% \mathrm{Cl}: 10.5 \%$ - 16.5\%) were newly diagnosed cases. Of these, only $13.2 \%(95 \% \mathrm{Cl}$ : $6.2 \%$ - 23.6\%) were diagnosed in infancy. Anaemia (94.1\%), sepsis $(79.5 \%)$ and painful crisis (54.3\%) were the most recorded clinical features. The mean values of haematological parameters were as follows: haemoglobin (g/dL) $6.4(\mathrm{SD}=1.9)$, platelets $\left(\times 10^{9} / \mathrm{L}\right) 358.8(\mathrm{SD}=200.9)$ while median value for white cell count $\left(\times 10^{9} /\right.$ L) was 23.5 (IQR: 18.0-31.2). Case fatality was $1.4 \%(95 \% \mathrm{Cl}: 0.6 \%$ - $2.8 \%)$ and $15.2 \%(95 \% \mathrm{Cl}$ : $12.2 \%-18.6 \%$ ) of the children had a prolonged hospital stay (>5days). Patients with painful crisis were 1.7 (95\% Cl: 1.02 - 2.86) times more likely to have prolonged hospital stay than those without the complication.

Conclusion Anaemia, sepsis and painful crisis were the most common clinical features paediatric patients with SCD presented with. Patients with painful crisis were more likely to have prolonged hospital stay. Delayed diagnosis of SCD is a problem that needs immediate attention in this setting. Although somewhat encouraging, the relatively low in-hospital mortality among SCD children may under-report the true mortality from the disease considering community deaths and deaths occurring before $\mathrm{SCD}$ diagnosis is made.

\section{INTRODUCTION}

Sickle cell disease (SCD) continues to be a major global public health concern. Data

\section{What is known about the subject?}

Sickle cell disease (SCD) remains a major cause of childhood mortality and morbidity in Malawi but literature to comprehensively describe the disease in the paediatric population is limited. So far, only two small scale single facility-based studies have been conducted.

- One of the studies focused on the progression of the pulmonary complications associated with SCD while the other one focused on the disparity in diagnoses between primary and secondary/tertiary level facilities.

\section{What this study adds?}

- Sickle cell disease (SCD) contributes a significan proportion of paediatric admissions in Malawi with anaemia, sepsis and painful crisis as the most common clinical features. Painful crisis is associated with prolonged hospital stay.

- The study further revealed that there is delayed diagnosis of SCD in our setting, and that mortality among hospitalised SCD children is relatively low.

indicate that, globally, an estimate of 400000 babies are born with SCD annually. ${ }^{1}$ SubSaharan Africa (SSA) bears the highest burden where up to $90 \%$ of the global births of the condition ${ }^{2}$ and about $50 \%-90 \%$ of childhood mortality occurs. ${ }^{3}$ Despite being one of the major killers for infants and children with high case fatality rates, it remains a condition of low priority in many countries. ${ }^{3}$ In an effort to scale up its management and control, SCD has been identified by WHO as an area requiring urgent and increased attention. ${ }^{4}$

In Malawi, particularly in the northern region, SCD is equally a significant cause of childhood morbidity and yet, receives relatively little attention compared with other 
childhood conditions. ${ }^{5}$ For instance, the country does not have a national repository to explain the burden of the disease. In addition, specific programmes for the prevention and control of SCD remain non-existent. Collectively, these factors have made the disease remain invisible and neglected while affected children continue to suffer from complications of the disease that demand lifelong care and support. Lack of awareness and recognition of SCD by local health authorities continue to make the disease an invisible health problem. ${ }^{6}$

Mzuzu Central Hospital (MCH) which is located in the northern region of Malawi is one of the four referral hospitals in the country. The hospital attends to a large number of patients with SCD, and clinical observations show that, at least five children with SCD are hospitalised weekly with various complications. However, there are no data to explain who these children are and how they fair clinically when admitted. There is lack of knowledge regarding the prevailing pattern of SCD admissions including the age most affected by the disease in Malawi.

Previous literature has described varied age distribution for children most affected by SCD. Studies conducted in Tanzania, Saudi Arabia and South Africa found the median age of admitted children with SCD or those attending clinic to be 6,7 and 8 years, respectively. ${ }^{7-9}$ Other studies conducted in Congo and Tanzania found much older children of median age of 10.5 and 14 years, respectively. ${ }^{1011}$

Children with SCD often suffer frequent hospitalisations due to various complications of the disease. Earlier studies have revealed varied complications of admitted paediatric patients. However, vaso-occlusive crisis, acute splenic sequestration, haemolytic crises, acute chest syndrome, stroke, pneumonia and severe infection have been reported as common reasons for admission in SCD children. ${ }^{7}$ 10-12 $^{12}$ Another study conducted in a paediatric SCD clinic in Malawi reported patient's histories of Malaria (39\%), anaemia (72\%), jaundice $(52 \%)$ and pain episodes $(50 \%){ }^{5}$

Effective management of these complications revolves around its prompt management. However, this is often compromised in the Malawian setting and other SSA region, due to limited resources. ${ }^{513}$ For instance, management of painful crises requires that, patients must be given supplemental oxygen, intravenous hydration and level 3 pain relievers such as morphine plus non-opioid and adjuvant. ${ }^{14}$ But due to inconsistent supply of medication in SSA, pain management is often restricted to level 2 analgesics. ${ }^{15}$

Similarly, hydroxyurea is not routinely prescribed in Malawi and universal use policy is not available despite documented evidence of its safety and efficacy ${ }^{16}$ Previous studies have attributed under utilisation of hydroxyurea to provider inexperience, cost and inaccessibility. ${ }^{1516}$ With regard to management of severe anaemia, local guidelines recommend supplemental oxygen and blood transfusion although this may be restricted due to limited supply of blood. Equally, monitoring of high-risk patients with SCD with transcranial Doppler ultrasound and prophylactic exchange transfusions are non-existent in Malawi. ${ }^{16}$ Collectively, these management gaps significantly contribute to high morbidity rate.

Furthermore, the haematological pattern of children with SCD appears to demonstrate a comparable trend. Studies conducted in South Africa, Tanzania, Nigeria and Ghana observed higher values of white cell count (WCC) and platelets but lower values of haemoglobin $(\mathrm{Hb})$ and red cell count (RCC). ${ }^{9} 111718$ Low Hb has been attributed to chronic haemolysis and shortened red cell lifespan and this further reduces RCCs.$^{18}$ On the other hand, the higher platelet count and WCC are attributed to a possible splenic sequestration and serious bacterial infection, respectively. ${ }^{19} 20$

There is paucity of data on the spectrum of SCD among hospitalised Malawian children. The current study seeks to investigate the demographic, clinical and haematological characterisation of admitted paediatric patients at MCH. This information would inevitably have substantial impact as it will provide a better understanding of the disease and facilitate development of specific disease management and control strategies.

\section{METHODS}

\section{Study design and setting}

This was a retrospective cross-sectional study of children admitted to MCH paediatric ward between July 2016 and June 2019. MCH is a teaching and regional referral hospital with a bed capacity of 410 , and serves a population of over 2289780 people. ${ }^{21}$ The department of paediatrics has a capacity of 60 inpatient beds and admit patients from 7 weeks to 12 years old.

\section{Study population and procedures}

Data were collected from clinical files of children with SCD. All files of patients with SCD aged 7 weeks to 12 years admitted to the ward during the study period were included in the study. Patients with other diagnoses other than SCD were not included in the study. First, clinical files of all patients admitted to the ward were screened in order to identify cases of SCD (figure 1). Patients were classified as having SCD if their hospital admission or discharge diagnoses or physician review notes included reference to a diagnosis of SCD.

These patients were further classified into two subgroups: patients already known to have SCD (herein referred to as known cases) and those in whom the diagnosis was made during the course of their hospitalisation (herein referred to as newly diagnosed cases). Patients were identified as known SCD cases based on documented evidence as indicated on admission form or doctors review notes while for newly diagnosed cases it was based on positive SCD laboratory result. The retrieved SCD cases underwent a detailed review to extract relevant data such as age, gender, clinical features, laboratory 


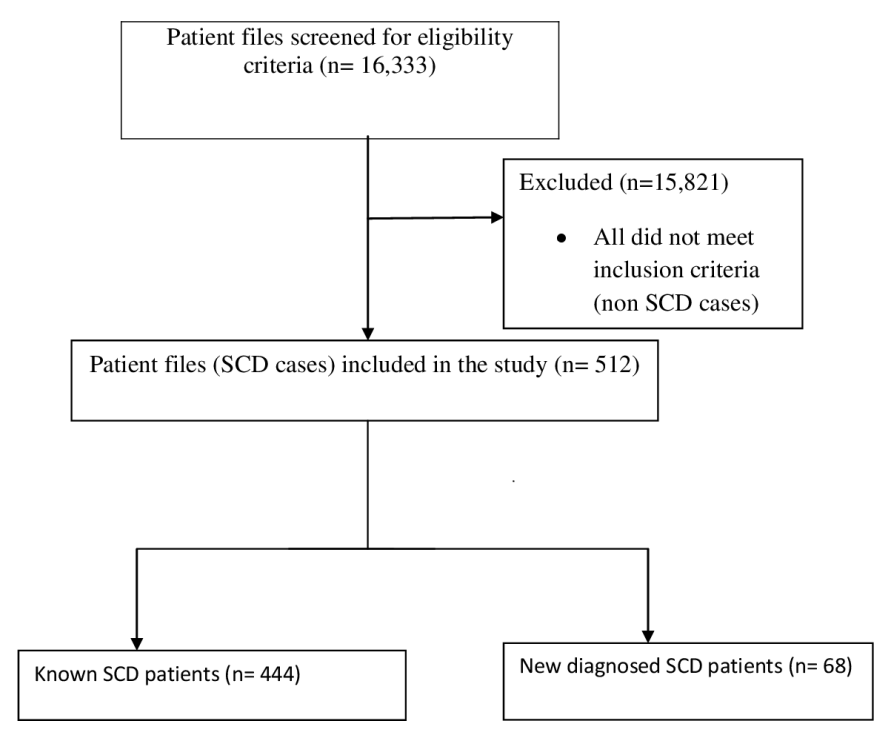

Figure 1 Screening and selection process of SCD clinical files.

investigations, outcome and length of hospital stay using a predesigned data extraction tool.

Development of the data extraction tool was determined by the clinical question and data source (clinical files). A multidisciplinary team including laboratory technologists, SCD medical, nursing and public health experts convened to develop an electronic data extraction tool. This involved formulating clear definitions of variables and coding process. ${ }^{22}$ Researchers performed weekly random database reviews against collected data to verify the coded elements.

Data abstractors composed of a medical doctor and professional nurse who had vast experience in SCD. They underwent a 1-day training on study protocol, which included purpose of the study, data extraction tool, screening and coding process, careful review of the variables and their definitions, instructions outlining how to treat incomplete/missing data and location of data in the patient's file.

With regard to SCD diagnosis; sickling tests were conducted using sodium metabisulfite. This test method is a phenotypic procedure which methodically reduces the oxygen tension inducing the typical sickle shape of RCCs. ${ }^{23}$ However, due to resource constraints in our setting, genotype confirmation was not conducted. Malaria infection was determined by malaria rapid diagnostic test which detects Plasmodium falciparum using Alere SD BIOLINE Malaria Ag P.f/Pan test, which is qualitative and differential test for the detection of antigen of Plasmodium. ${ }^{24}$ Full blood counts analysis was conducted by Sysmex Hematology Analyzer (Sysmex XP-300 Automated Haematology Analyzer) which uses $50 \mu \mathrm{L}$ on whole blood $^{25}$ (see online supplemental file 1 ).

\section{Definitions}

We applied the following definitions for the purpose of our analysis: vaso-occlusive episode was defined as a new episode of acute pain requiring hospitalisation which results from tissue ischaemia. ${ }^{26}$ Acute chest syndrome was defined as acute respiratory illness with fever and/or respiratory symptoms such as cough, dyspnoea, tachypnoea or hypoxia requiring hospitalisation. ${ }^{26}$ Dactylitis was defined as a new episode of acute pain and swelling in the fingers or toes due to vaso-occlusion and is usually associated with fever. ${ }^{27}$ Priapism was defined as painful, persistent, unwanted erection of the penis. ${ }^{26}$ Hepatic sequestration was defined as sequestration of RCCs in hepatic sinusoids, leading to liver enlargement and decreased $\mathrm{Hb}$ concentration. ${ }^{26}$ Acute splenic sequestration was defined as rapid intrasplenic trapping of sickle cells, which causes a precipitous fall in $\mathrm{Hb}$ level and spleen enlargement. ${ }^{26}$ Leg ulcers was defined as the ulceration of the skin of the legs with prolonged wound healing requiring medical attention for wound treatment, debridement or dressings. ${ }^{26}$ Jaundice was defined as yellowish pigmentation of the skin and sclera ${ }^{27}$ while Arthritis was defined as acute or chronic inflammation of a joint, often accompanied by pain, stiffness, warmth, swelling and redness. ${ }^{26}$ Clinically, anaemia was defined as the presence of pallor conjunctivae, mucous membranes, nail beds and palms. ${ }^{28}$ The laboratory definition of anaemia was acute lowering of the $\mathrm{Hb}$ level below normal reference ranges ${ }^{27}$ while severe anaemia was defined as $\mathrm{Hb}$ level of less than $4 \mathrm{~g}$ / $\mathrm{dL} .{ }^{14}$ Sepsis was considered to be the presence of fever with a negative malaria parasite test, and/or raised WCC. ${ }^{27}$

\section{Patient and public involvement}

This study did not involve patients nor the public as it was a retrospective cross-sectional study and data were obtained from medical case files.

\section{Data analysis}

Data were entered in Microsoft excel 2016, validated and cleaned before importing into Stata, V.13.0 (StataCorp) for analysis. Descriptive statistics were performed to summarise patients' demographic, clinical and haematological characteristics. $\chi^{2}$ or Fisher's exact test was performed to explore associations between predictor variables and outcome variables (case fatality and length of hospital stay). A $\chi^{2}$ test was performed for all crosstabulations where the sample size (n) was greater than the number of cells multiplied by 5 and where the expected value in $80 \%$ of the contingency cells was greater than 5 and no cell had the expected value of less than 3. Where this condition was not met, a Fisher's exact test was performed instead. A p value of 0.05 or less was considered statistically significant. Only those predictor variables which had a statistically significant association with outcome variables (painful crisis, splenic sequestration and hepatic sequestration) were carried forward for analysis in a binary logistic regression and adjusted for, in a multivariable binary logistic regression. Length of hospital stay was dichotomised into $\leq 5$ days and $>5$ days because children presenting with sepsis are often put on a 5-day course of parenteral antibiotics. These children 
Table 1 Demographic characteristics of patients with SCD

\begin{tabular}{lc}
\hline Characteristic & Frequency (\%) \\
\hline $\begin{array}{l}\text { Sex } \\
\text { Male }\end{array}$ & $298(58.2)$ \\
\hline Female & $214(41.8)$ \\
\hline $\begin{array}{l}\text { Age (months) } \\
<12\end{array}$ & $25(4.9)$ \\
\hline $12-59$ & $227(44.3)$ \\
\hline$\geq 60$ & $260(50.8)$ \\
\hline $\begin{array}{l}\text { SCD History } \\
\text { Known cases }\end{array}$ \\
\hline $\begin{array}{l}\text { Newly diagnosed cases } \\
\text { Age (months) for newly diagnosed cases during study period } \\
\text { (n=68) }\end{array}$ \\
\hline$<12$ & $444(86.7)$ \\
\hline $12-59$ & $98(13.2)$ \\
\hline$\geq 60$ & $40(58.8)$ \\
\hline Length of hospital stay & $19(27.9)$ \\
\hline$\leq 5$ days & $434(84.8)$ \\
\hline$>5$ days & $78(15.2)$ \\
\hline Case fatality & $7(1.4)$ \\
\hline
\end{tabular}

Median age=60 months (IQR: 30.5-108 months); median length of stay=3 days (IQR: 2-5 days).

cannot be discharged from hospital before they complete their treatment course even if their condition improves substantially before day 5 that they qualify for discharge. Therefore, putting the cut point at day 5 took care of the prolonged hospital stay which was due to treatment being received and allowed us to explore hospital stay which was purely due to the condition of the patient.

\section{RESULTS}

Of the 16333 paediatric hospitalisations, 512 were SCD children, representing $3.1 \%$. There were more males $(58 \%)$ than females. Out of 512 patients, 68 (13.3\%) were newly diagnosed SCD cases. Nine $(13.2 \%)$ of these were diagnosed in infancy (before 12 months of life), while $19(27.9 \%)$ after their fifth birthday. Seventy-eight children $(15.2 \%)$ were hospitalised for more than 5 days. Seven children $(1.4 \%)$ died (table 1$)$.

The most recorded clinical features were anaemia (94.1\%), sepsis $(79.5 \%)$ and painful crisis $(54.3 \%)$. Leg ulcers, priapism and dactylitis were the least common clinical features representing $0.6 \%, 1.0 \%$ and $0.6 \%$, respectively. In addition, $68(16.4 \%)$ patients had malaria, diagnosed using rapid diagnostic test (table 2).

Routine full blood counts showed that the mean $\mathrm{Hb}$ count was $6.4 \mathrm{~g} / \mathrm{dL}(\mathrm{SD}=1.9)$. Forty-four children had $\mathrm{Hb}$ concentration of $<4 \mathrm{~g} / \mathrm{dL}$. The mean count for RCCs, WCCs and platelets were 2.4 $(\mathrm{SD}=0.6), 26.4(\mathrm{SD}=14.6)$ and $358.8 \quad(\mathrm{SD}=200.9)$, respectively (table 3$)$. These parameters were compared against the normal reference limits of the haematology analyser (Sysmex XP 300).

There were no statistically significant associations between clinical features and case fatality. Significant associations were, however, observed between length of hospital stay and painful crisis $(p=0.03)$, hepatic sequestration $(\mathrm{p}=0.01)$ and splenic sequestration $(\mathrm{p}=0.03)$ (table 4). In a univariable logistic regression patients with painful crisis, splenic and hepatic sequestration were 1.7,

\begin{tabular}{|c|c|c|c|c|}
\hline Clinical feature & $\begin{array}{l}<12 \text { months }(n=25) \\
n(\%)\end{array}$ & $\begin{array}{l}12-59 \text { months }(\mathrm{n}=227) \\
\mathrm{n}(\%)\end{array}$ & $\begin{array}{l}\geq 60 \text { months }(n=260) \\
n(\%)\end{array}$ & $\begin{array}{l}\text { Total }(n=512) \\
n(\%)\end{array}$ \\
\hline Anaemia & 23 (92.0) & $212(93.4)$ & $247(95.0)$ & $482(94.1)$ \\
\hline Severe anaemia* & $0(0.0)$ & $17(8.6)$ & 27 (12.0) & $44(9.9)$ \\
\hline Sepsis & $22(88.0)$ & $191(84.1)$ & 194 (74.6) & 407 (79.5) \\
\hline Painful crisis & $12(48.0)$ & 89 (39.2) & $177(68.1)$ & 278 (54.3) \\
\hline Jaundice & $11(44.0)$ & $62(27.3)$ & $106(40.8)$ & $179(35.0)$ \\
\hline Pneumonia & $10(40.0)$ & 65 (28.6) & $40(15.4)$ & $115(22.5)$ \\
\hline Acute chest syndrome & $3(12.0)$ & $14(6.2)$ & $16(6.2)$ & $17(6.6)$ \\
\hline Arthritis & $4(16.0)$ & $32(14.1)$ & $44(16.9)$ & 80 (15.6) \\
\hline Splenic sequestration & $3(12.0)$ & $30(13.2)$ & $27(10.4)$ & $60(11.7)$ \\
\hline Hepatic sequestration & $3(12.0)$ & $18(7.9)$ & $21(8.1)$ & $42(8.2)$ \\
\hline Leg ulcers & $0(0.0)$ & $1(0.4)$ & $2(0.8)$ & $3(0.6)$ \\
\hline Priapism (n/N (\%)† & $0 / 12(0.0)$ & $1 / 127(0.8)$ & 2/159 (1.3) & 3/298 (1.0) \\
\hline Dactylitis & $3(12.0)$ & $0(0.0)$ & $0(0.0)$ & $3(0.6)$ \\
\hline Malaria $(\mathrm{n} / \mathrm{N}(\%) \ddagger$ & $0 / 23(0.0 \%)$ & $33 / 184(17.9)$ & $35 / 207(16.1)$ & 68/414 (16.4\% \\
\hline
\end{tabular}

${ }^{*}$ Severe anaemia $(\mathrm{Hb}$ level $<4 \mathrm{~g} / \mathrm{dL})$.

$\mathrm{tn} / \mathrm{N}$ is included where the symptom is applicable to males only.

$\mp n / N$ is included where not everyone was tested for malaria. 
Table 3 Haematological parameters of SCD children admitted at $\mathrm{MCH}$

\begin{tabular}{llllll} 
Parameter (unit) & $\mathbf{n}$ & Mean (SD) & Median (IQR) & Range & Reference range \\
\hline $\mathrm{RCC}\left(\times 10^{12} / \mathrm{L}\right)$ & 322 & $2.4(0.8)$ & & $0.6-6.3$ & $4-6$ \\
$\mathrm{Hb}(\mathrm{g} / \mathrm{dL})$ & 445 & $6.4(1.9)$ & & $1.4-12$ & $10.9-17.3$ \\
$\mathrm{MCV}(\mathrm{fL})$ & 310 & $82.8(10.3)$ & $43.1-121.6$ & $71-95$ \\
$\mathrm{MCHC}(\mathrm{g} / \mathrm{dL})$ & 303 & $33.2(2.7)$ & $22.3-51.0$ & $33-36$ \\
$\mathrm{WCC}\left(\times 10^{9} / \mathrm{L}\right)$ & 407 & - & $23.5(18.0-31.2)$ & $2.7-145.4$ & $4-10$ \\
Platelets $\left(\times 10^{9} / \mathrm{L}\right)$ & 380 & $358.8(200.9)$ & & $11-1424$ & $122-330$ \\
\hline
\end{tabular}

One child had WCC of 338.6 and was excluded from the WCC analysis because was considered as an extreme outlier. Other conditions might have been responsible for such an elevated WCC. The mean for RCC, platelets and the median for WCC are all outside the reference ranges. Different n's for different FBC parameters are due to missing data.

MCV: Mean Corpuscular Volume; MCHC: Mean Corpuscular Haemoglobin Concentration.

$\mathrm{Hb}$, haemoglobin; RCC, red cell count; WCC, white cell count.

2.1 and 2.4 times, respectively, more likely to be hospitalised for more than 5 days than those without these complications. However, in multivariable analysis, only painful crisis (OR=1.7; 95\% CI: 1.02- 2.86) was significantly associated with length of hospital stay (table 4).

\section{DISCUSSION}

Our study provides a description of paediatric SCD in Malawi. There has been relatively limited information about the spectrum of paediatric SCD in our setting when compared with information available from other African countries and beyond. Our study has established that SCD contributes a considerable proportion of paediatric admission in our setting. It has further revealed delayed SCD diagnosis, common clinical features (anaemia, sepsis, painful crisis) and low haematological parameters and case fatality rate in our study population.

Our study has revealed that, SCD contributed a significant proportion $(3.1 \%)$ among the admitted children. These results are slightly higher compared with findings documented in Kuwait,Kenya, Sudan and Uganda where SCD contributed to about $0.6 \%, 0.8 \%, 1.5 \%$ and $0.7 \%$, respectively. ${ }^{129-31}$

Findings from our study have further revealed that, only $13.2 \%$ of the patients were diagnosed with SCD during infancy, up to $58.8 \%$ between the ages of 12 and 59 months, and more than a quarter $(26.5 \%)$ got diagnosed after their fifth birthday. These findings provide evidence of delayed diagnosis in Malawi. This is not surprising given that routine new-born screening programmes are non-existent. As a result, diagnosis is often made late and follow-up of suspected cases are rarely done. ${ }^{52}$ There is no specific age for diagnosis of SCD in Malawi, a situation which is similar to other African countries. ${ }^{33}$

The case fatality of $1.4 \%$ in our study is slightly lower compared with previous studies conducted in Tanzania, Malawi, Kenya and Brazil which reported varied mortality frequencies of $1.9 \%, 3.8 \%, 4.5 \%$ and $7.4 \%$, respectively. ${ }^{32}{ }^{34-36}$ However, our in-hospital mortality is more likely an underestimate of the total mortality from SCD as many children may have died at home before diagnosis of
SCD was made. ${ }^{9}$ These results must, therefore, be interpreted with caution. A substantial proportion (15.2\%) of the children had a prolonged hospital stay ( $>5$ days) which is known to be associated with increased mortality and economic burden on the health system and families. ${ }^{37}$

In our study, anaemia was the most recorded clinical feature in patients with SCD followed by sepsis and painful crisis, representing 94.1\%, $79.5 \%$ and $54.3 \%$, respectively. These features were based on clinical presentation at the time of admission. However, the mean $\mathrm{Hb}$ of our patients was $6.4 \mathrm{~g} / \mathrm{dL}$, which was similar to those recorded in a steady state paediatric population in Nigeria $(6.9 \mathrm{~g} / \mathrm{dL}) .{ }^{38}{ }^{39}$ This suggests that, most of our hospitalised children had $\mathrm{Hb}$ levels that were normal for children with SCD. It is, therefore, not surprising to note that only $9.9 \%$ of the patients had severe anaemia $(\mathrm{Hb}<4 \mathrm{~g} / \mathrm{dL}$ ) requiring blood transfusion according to Malawian treatment guidelines. ${ }^{14}$ This emphasises the need to verify clinical and subjective diagnoses of anaemia with laboratory investigation in patients with SCD so as to confirm the severity of anaemia and institute appropriate management for the patients.

Painful crisis was the third common clinical feature observed in our study, contrary to previous studies where it was the top most complication for children with SCD. ${ }^{7812}$ This could likely be as a result of positive efforts by the hospital in educating parents on the prevention of pain triggers at home which includes maintaining adequate oral hydration, avoiding strenuous exercises, keeping the child warm when it is cold but also to avoid getting too hot. These educational sessions are facilitybased initiatives, which are conducted quarterly through a parent support group programme.

The frequency of leg ulcers $(0.6 \%)$, priapism $(1 \%)$ and dactylitis $(0.6 \%)$ in our study was low which is consistent with previous studies conducted in Congo and Saudi Arabia. ${ }^{1040}$ The prevalence of leg ulcers and dactylitis is generally low in younger children. ${ }^{41}$ In addition, the low frequency could be due to a small sample for this age group in our study. On the other hand, some studies indicate that the prevalence of priapism is usually low due 


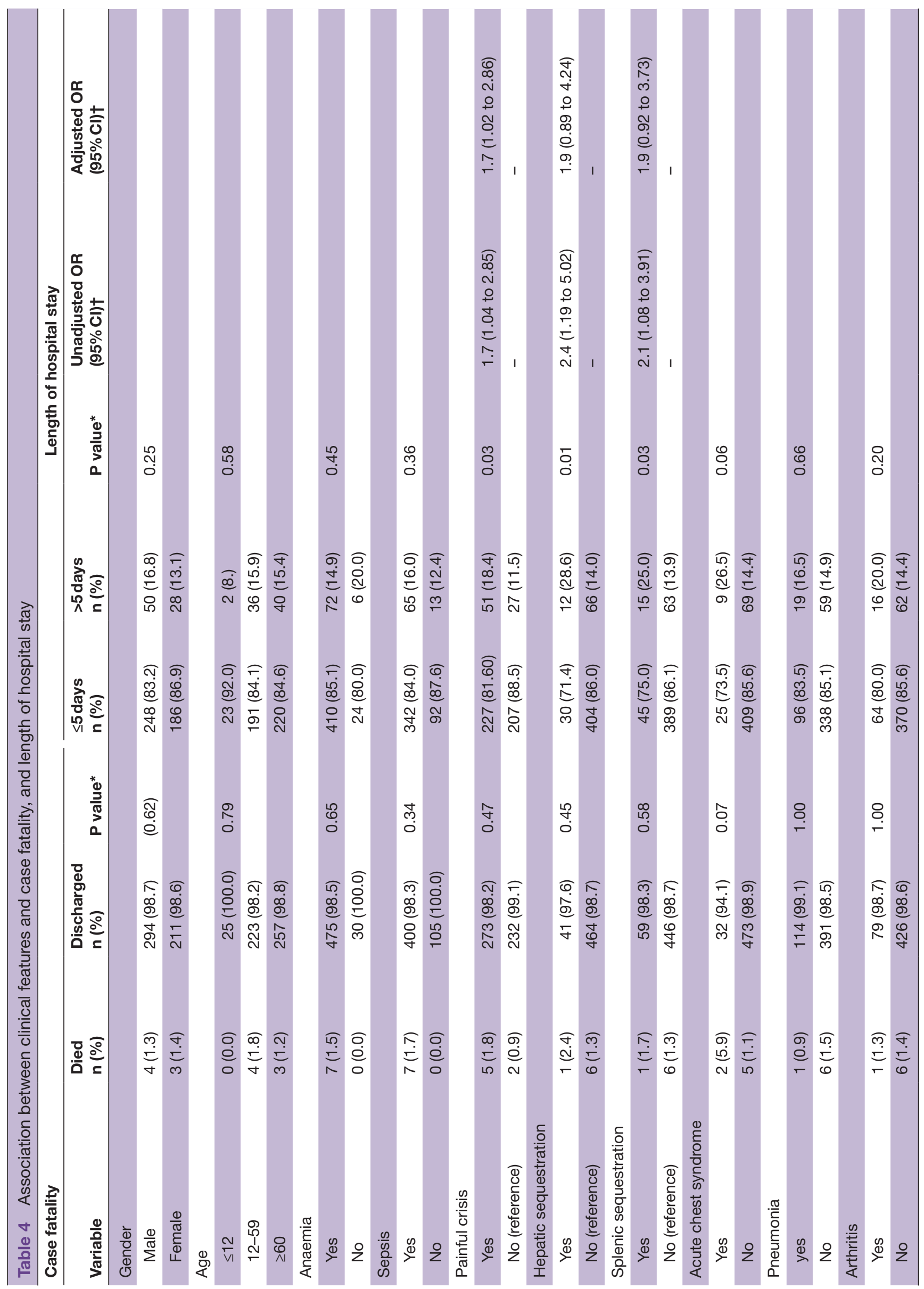




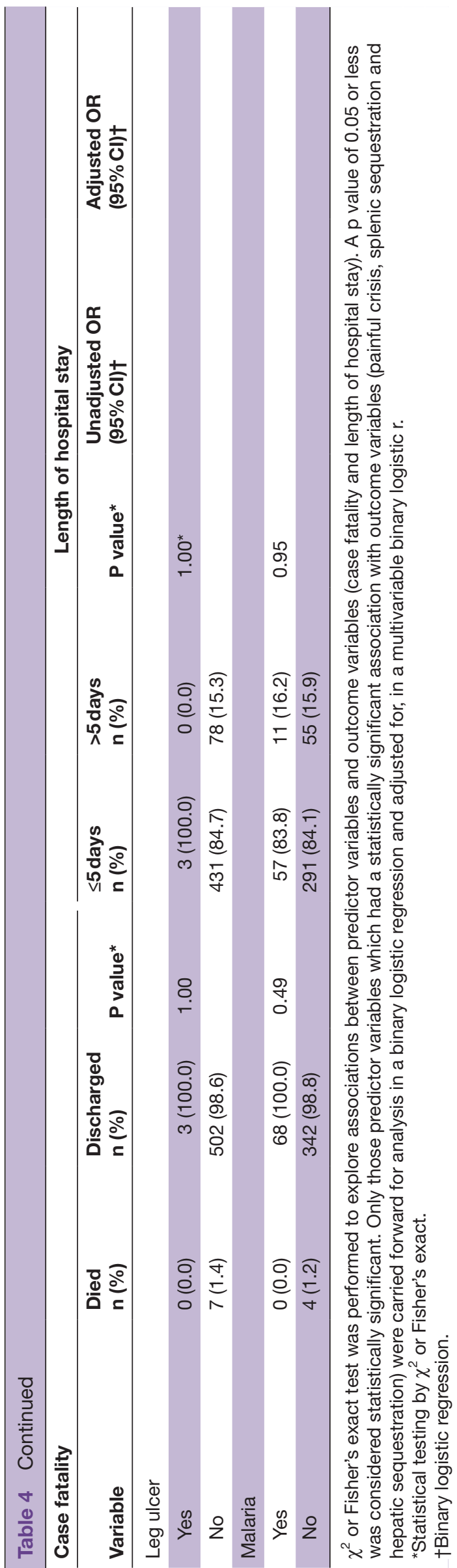

to lack of awareness by physicians and under-reporting by patients. ${ }^{42}$ This could be true in this study given the young age of patients under the study.

Malaria was diagnosed in $68(16.4 \%)$ patients. Unfortunately, our study does not have comparative data to determine how these findings compare with those in children without SCD. Nonetheless, our findings are relatively higher than previous studies conducted in Tanzania and Kenya which recorded $11.6 \%$ and $15.6 \%$, respectively. ${ }^{1134}$ We are unable to determine the cause for such a high frequency because according to Malawian guidelines, all patients with SCD are given antimalaria prophylaxis (sulfadoxine pyrimethamine) every month. ${ }^{14}$ This calls for more research to understand the role of the antimalaria prophylaxis in patients with SCD.

As expected, the mean for RCC, WCC and platelets were all outside the normal reference ranges. Previous studies observed similar findings ${ }^{1718}$ and this is attributed to chronic haemolysis, higher risk of infections and chronic pain in patients with SCD. ${ }^{17}$

We did not find any significant associations between case fatality and clinical features unlike previous studies which found significantly higher mortality in patients with infection. ${ }^{43}$ The discrepancy may be due to the fact that there were very few events (deaths) in our study (see online supplemental file 2). On the other hand, our study found that painful crisis, splenic and hepatic sequestrations were the complications that lead to longer ( $>5$ days) hospital stay. Another previous study also observed longer hospital stay for painful crisis. ${ }^{44}$ In our setting, this might be as a result of inadequate use of clinical guidelines to manage these complications. Enforcing adherence to clinical guidelines may help in proper management of these complications which will ultimately lead to quick recovery.

\section{Limitations and recommendations}

Our study had some limitations. The most critical one being missing data as it was collected from clinical files. Due to lack of diagnostic capacity in our setting, some of the patients' diagnoses were often determined on clinical basis. In addition, the test which was conducted to diagnose SCD has a low specificity given that it cannot distinguish sickle cell trait from SCD. Furthermore, there is a possibility that some children may have been admitted more than once, but this may not critically affect the interpretation of our results given that the focus of this study was to understand the clinical presentation of all paediatric SCD hospitalisations.

Despite these limitations, our study has provided a description of the clinical picture of paediatric SCD in Malawi, highlighting the need for diagnostic newborn screening and SCD registries in Malawi. The authors further recommend the need for low-cost life-saving interventions for SCD management in low-resource settings. Although we have provided data that will inform policy regarding paediatric SCD in Malawi, the study has also highlighted areas for further research. We 
propose that priority should be given to a study seeking to describe the management of hospitalised SCD children in order to identify gaps in the care process so that measures to improve survival and reduce hospital stay can be instituted.

\section{CONCLUSION}

SCD contributes a significant proportion in paediatric hospitalisations, with anaemia, sepsis and painful crisis being the most common clinical presentations of hospitalised children. Painful crisis was associated with longer hospital stay. Delayed diagnosis of SCD is a problem that needs immediate redress in this setting. Although the relatively low in-hospital mortality among SCD children is somewhat encouraging, this estimate may under-report the true mortality from the disease considering community deaths and deaths occurring before SCD diagnosis is made.

\author{
Author affiliations \\ 'Paediatrics, Mzuzu Central Hospital, Mzuzu, Northern Region, Malawi \\ ${ }^{2}$ Biological Sciences, Mzuzu University Faculty of Health Sciences, Mzuzu, Northern \\ Region, Malawi \\ ${ }^{3}$ Laboratory, Mzuzu Central Hospital, Mzuzu, Northern Region, Malawi \\ ${ }^{4}$ Medicine, Mzuzu Central Hospital, Mzuzu, Northern Region, Malawi \\ ${ }^{5}$ Department of Public Health, Faculty of Applied Sciences, University of \\ Livingstonia, Mzuzu, Northern Region, Malawi \\ ${ }^{6}$ University of Maryland Global Initiatives Corporation Baltimore, Lilongwe, Central \\ Region, Malawi \\ ${ }^{7}$ Luke International, Mzuzu, Northern Region, Malawi \\ ${ }^{8}$ Ping Tung Christian Hospital, Pingtung, Taiwan
}

Contributors CSC conceived and designed the study protocol, assisted with data cleaning, interpretation, drafted the initial manuscript and wrote the final manuscript. FWS and MC drafted the protocol, reviewed and revised the manuscript. PK, BCM, PUK and T-SJW contributed to the development of study protocol, data entry and interpretation, reviewed and revised the manuscript. AK drafted the study protocol, analysed the data, reviewed and revised the manuscript. All authors read and approved the final manuscript.

Funding This work was supported by Pingtung Christian Hospital, Taiwan through Luke International Norway-Malawi, grant number (PS-IR-108001).

Competing interests None declared.

Patient consent for publication Not required.

Ethics approval Ethical approval to conduct the study was obtained from The National Health Sciences Research Committee (NHSRC) with protocol number: 19/05/2320. Clearance was granted by MCH Research and Publication Committee and the $\mathrm{MCH}$ administration to access patients' clinical files.

Provenance and peer review Not commissioned; externally peer reviewed.

Data availability statement Data are available on reasonable request. The dataset supporting the conclusions of this study is available from the corresponding author upon reasonable request.

Supplemental material This content has been supplied by the author(s). It has not been vetted by BMJ Publishing Group Limited (BMJ) and may not have been peer-reviewed. Any opinions or recommendations discussed are solely those of the author(s) and are not endorsed by BMJ. BMJ disclaims all liability and responsibility arising from any reliance placed on the content. Where the content includes any translated material, BMJ does not warrant the accuracy and reliability of the translations (including but not limited to local regulations, clinical guidelines, terminology, drug names and drug dosages), and is not responsible for any error and/or omissions arising from translation and adaptation or otherwise.

Open access This is an open access article distributed in accordance with the Creative Commons Attribution Non Commercial (CC BY-NC 4.0) license, which permits others to distribute, remix, adapt, build upon this work non-commercially, and license their derivative works on different terms, provided the original work is properly cited, appropriate credit is given, any changes made indicated, and the use is non-commercial. See: http://creativecommons.org/licenses/by-nc/4.0/.

\section{ORCID iDs}

Chikondi Sharon Chimbatata http://orcid.org/0000-0001-6663-8785

Master RO Chisale http://orcid.org/0000-0002-8301-6184

Balwani Chingatichifwe Mbakaya http://orcid.org/0000-0002-4705-9064

Tsung-Shu Joseph Wu http://orcid.org/0000-0001-6155-9340

\section{REFERENCES}

1 Kato GJ, Piel FB, Reid CD, et al. Sickle cell disease. Nat Rev Dis Primers 2018;4:18010.

2 McGann PT. Time to invest in sickle cell anemia as a global health priority. Pediatrics 2016;137:e20160348-11.

3 Grosse SD, Odame I, Atrash HK, et al. Sickle cell disease in Africa. Am J Prev Med 2011;41:S398-405.

4 World Health Organization. Sickle-Cell anaemia: report by the Secretariat. provisional agenda item 11.4. 59th World health assembly, 2006. Available: http://apps.who.int/gb/archive/pdf_files / WHA59/A59_9-en.pdf [Accessed 21 Mar 2020].

5 Heimlich JB, Chipoka G, Kamthunzi P, et al. Establishing sickle cell diagnostics and characterizing a paediatric sickle cell disease cohort in Malawi. Br J Haematol 2016;174:325-9.

6 Mburu J, Odame I. Sickle cell disease: reducing the global disease burden. Int J Lab Hematol 2019;41:82-8.

7 Saidi H, Smart LR, Kamugisha E, et al. Complications of sickle cell anaemia in children in northwestern Tanzania. Hematology 2016;21:248-56.

8 Alkot M, Almaghrabi WA, Najdi NA, Al NN, et al. Prevalence of complications of sickle cell disease at Makkah Al-Mukaramah, Saud Arabia, 2017. Ann Clin Lab Res 2018;06.

9 Wonkam A, Ponde C, Nicholson N, et al. The burden of sickle cell disease in Cape town. S Afr Med J 2012;102:752.

10 Aloni MN, Kadima BT, Ekulu PM, et al. Acute crises and complications of sickle cell anemia among patients attending a pediatric tertiary unit in Kinshasa, Democratic Republic of Congo. Hematol Rep 2017:9:6952.

11 Sawe HR, Reynolds TA, Mfinanga JA, et al. The clinical presentation, utilization, and outcome of individuals with sickle cell anaemia presenting to urban emergency department of a tertiary hospital in Tanzania. BMC Hematol 2018;18:25.

12 Akar NA, Adekile A. Ten-Year review of hospital admissions among children with sickle cell disease in Kuwait. Med Princ Pract 2008;17:404-8.

13 Mulumba LL, Wilson L. Sickle cell disease among children in Africa: an integrative literature review and global recommendations. Int $J$ Afr Nurs Sci 2015;3:56-64.

14 Guidelines O. Open guidelines: electronic protocols for the management of common childhood illnesses in Malawi, 2018. Available: https://play.google.com/store/apps/details?id=net. misssophie.www.openguidelines\&hl=en\&gl=US [Accessed 21 Nov 2020].

15 Mukinayi Mbiya B, Tumba Disashi G, Gulbis B, Mbiya BM, Disashi GT. Sickle cell disease in the Democratic Republic of Congo: assessing physicians' knowledge and practices. Trop Med Infect Dis 2020;5:127.

16 Mvalo T, Topazian H, Kamthunzi P, et al. Increasing hydroxyurea use in children with sickle cell disease at Kamuzu central Hospital, Malawi. Blood Adv 2018:2:30-2.

17 Akinbami A, Dosunmu A, Adediran A, et al. Haematological values in homozygous sickle cell disease in steady state and haemoglobin phenotypes AA controls in Lagos, Nigeria. BMC Res Notes 2012;5:396.

18 Antwi-Boasiako C, Ekem I, Abdul-Rahman M, et al. Hematological parameters in Ghanaian sickle cell disease patients. J Blood Med 2018:9:203-9.

19 Franceschi L, Cappellini M, Olivieri O. Thrombosis and sickle cell disease. Semin Thromb Hemost 2011;37:226-36.

20 Ahmed AE, Ali YZ, Alsuliman A, et al. The prevalence of abnorma leukocyte count, and its predisposing factors, in patients with sickle cell disease in Saudi Arabia. J Blood Med 2017;8:185-91.

21 National Statistical Office. Malawi population and housing census: main report, 2018. Available: http://populationmalawi.org/wp1/wpcontent/uploads/2019/10/2018-Malawi [Accessed 31 Jan 2020].

22 Sarkar S, Seshadri D. Conducting record review studies in clinical practice. J Clin Diagnostic Res 2014;8:1-4.

23 Old J, Harteveld CL, Traeger-Synodinos J. Thalassaemia International Federation. 2 edn, 2012. 
24 Sd Bioline malaria Ag P.f/Pan | Abbott point of care testing. Available: https://www.globalpointofcare.abbott/en/product-details/ sd-bioline-malaria-ag-p-f-pan.html [Accessed 6 Jul 2021].

25 XP-300-Hematology-Analyzer. Available: https://www.sysmex.com/ us/en/ Products/ Hematology/3PartDiff/Pages/XP-300-HematologyAnalyzer.aspx [Accessed 6 Jul 2021].

26 Ballas SK, Lieff S, Benjamin LJ, et al. Definitions of the phenotypic manifestations of sickle cell disease. Am J Hematol 2010;85:6-13.

27 Ministry of Health. Malawi standard treatment guidelines: incorporating Malawi essential medicines list (MEML). 4th ED, 2009. Available: http://apps.who.int/medicinedocs/en/d/Js18801en/ [Accessed 24 Apr 2021].

28 Sheth TN, Choudhry NK, Bowes M, et al. The relation of conjunctival pallor to the presence of anemia. J Gen Intern Med 1997;12:102-6.

29 Uyoga S, Macharia AW, Mochamah G, et al. The epidemiology of sickle cell disease in children recruited in infancy in Kilifi, Kenya: a prospective cohort study. Lancet Glob Health 2019;7:e1458-66.

30 Elderdery A, Adam NK, Mohamed BA. Haemoglobinopathies in the Northern Darfur state, stratified by tribes and ages. Int $J$ Biomed Adv Res 2015;6:864-7.

31 Ndeezi G, Kiyaga C, Hernandez AG, et al. Burden of sickle cell trait and disease in the Uganda sickle surveillance study (US3): a crosssectional study. Lancet Glob Health 2016;4:e195-200.

32 Kamthunzi P, Topazian H, Mvalo T, et al. Development of sickle cell diagnostics and a pediatric sickle cell clinic in Malawi. Blood Adv 2018;2:14-16.

33 Akodu F, Diaku-Akinwumi IN, Njokanma OF. Age at diagnosis of sickle cell anaemia in Lagos, Nigeria. Mediterr J Hematol Infect Dis 2013:5:e2013001.

34 Komba AN, Makani J, Sadarangani M, et al. Malaria as a cause of morbidity and mortality in children with homozygous sickle cell disease on the coast of Kenya. Clin Infect Dis 2009;49:216-22.
35 Odunvbun ME, Okolo AA. Implementing comprehensive health care management for sickle cell disease in an African setting. Niger $J$ Paediatr 2015;42:298.

36 Sabarense AP, Lima GO, Silva LML, et al. Characterization of mortality in children with sickle cell disease diagnosed through the newborn screening program. J Pediatr 2015;91:242-7.

37 Marfil-Garza BA, Belaunzarán-Zamudio PF, Gulias-Herrero A, et al. Risk factors associated with prolonged Hospital length-of-stay: 18year retrospective study of hospitalizations in a tertiary healthcare center in Mexico. PLoS One 2018;13:e0207203-17.

38 Akodu SO, Njokanma OF, AdeoluKehinde O. Erythrocyte indices in pre-school Nigerian children with sickle cell anaemia in steady state. Int J Hematol Oncol Stem Cell Res 2015;9:5-9.

39 Iheanacho $\mathrm{O}$. Haematological parameters of adult and paediatric subjects with sickle cell disease in steady state, in Benin City, Nigeria. IBRR 2015;3:171-7.

40 Alhumaid A, Aleidi A, Alfakhri A. Clinical features and outcome of sickle cell anemia in a tertiary center: a retrospective cohort study. $J$ Appl Hematol 2018;9:22.

41 Quinn CT. Sickle cell disease in childhood: from newborn screening through transition to adult medical care. Pediatr Clin North Am 2013;60:1363-81.

42 Arduini GAO, Trovó de Marqui AB. Prevalence and characteristics of priapism in sickle cell disease. Hemoglobin 2018;42:73-7.

43 Loureiro MM, Rozenfeld S, Portugal RD. Acute clinical events in patients with sickle cell disease: epidemiology and treatment. Rev Bras Hematol Hemoter 2008;30:95-100.

44 Rogovik AL, Li Y, Kirby MA, et al. Admission and length of stay due to painful vasoocclusive crisis in children. Am J Emerg Med 2009;27:797-801. 